\title{
Effect of using Chitosan and Rosemary in Extending the Shelf Life of Refrigerated Orechromis niloticus Fillets
}

\author{
Ahmed,A.H. , Shaltout,O.E. , Abou Elyazid,A.M. , El bermawi,N.M. \\ Dept. of Food Science, Fac. of Agric, (Saba Basha)., Alex. Univ., Egypt
}

\begin{abstract}
The present work was undertaken to examine the effect of chitosan and rosemary in extending the shelf life of refrigerated Nile tilapia(orechromis niloticus) fillets .

Three different treatments ( chitosan "C" , rosemary "R" , a mix of them "C+R") beside the control were prepared. Chitosan solution was prepared at $1.5 \%(\mathrm{w} / \mathrm{v})$ in $1 \% \mathrm{v} / \mathrm{v}$ acetic acid. Rosemary solution was prepared as the chitosan solution. The mix of chitosan and rosemary solution was prepared with $1 \%(\mathrm{w} / \mathrm{v})$ chitosan with $1 \%(\mathrm{w} / \mathrm{v})$ rosmary in $1 \% \mathrm{v} / \mathrm{v}$ acetic acid following the same procedure of chitosan preparation. The samples were coated and stored at ( $4 \pm 1{ }^{\circ} \mathrm{C}$ ) for 15 days and sampling was done periodically at $0,3,6,9,12,15$ days. Microbiological, chemical and sensory attributes were periodically assessed. The results indicated that the three pretreatments could more effectively maintain quality and could extend the shelf life by 3-6 days compared to the control group during refrigerated storage.
\end{abstract}

Keywords : chitosan, rosemary, fillets, nile tilapia, coated meet .

\section{INTRODUCTION}

The heightened demands by consumers for better quality and improved freshness of food products have given rise to the development and implementation of edible production technique such as edible films. Edible films or coatings are defined as continuous matrices that can be prepared from proteins, polysaccharides, and lipids. The use of edible films helps to maintain product quality, enhance sensory properties, improve product safety, and increase the shelf life of various ready-to-eat (RTE) food products (Cagri et al., 2004; Bonilla et al., 2012; Campos et al., 2011).

Chitosan, derived by the deacetylation of chitin (poly-b-(1-4)-N-acetyl-Dglucosamine), is a major component of the crustacean shells such as crab, shrimp, and crawfish (No et al., 2002). Chitosan has been reviewed for commercial application in the biomedical, food, and chemical industries (Muzzarelli, 1977; Knorr, 1984). Due to its biological activities, such as the antimicrobial activity (Kendra and Hadwiger, 1984; Sudarshan et al., 1992; Sekiguchi et al., 1994; Fang et al., 1994; Chen et al., 1998; Tsai and Su, 1999; No et al., 2002; Tsai et al., 2004; Kong et al., 2010), antitumor (Suzuki et al., 1986; Tokoro et al., 1988), and hypocholesterolemic functions (Sugano et al., 1980), chitosan and its oligomers have received considerable attention. Chitosan is a good candidate for an antimicrobial film due to its film-forming properties (Darmadji and Izumimoto, 1994). 
Numerous studies have indicated that lipid oxidation in fish and fish products may be inhibted through the use of chitosan (Jeon et al., 2002; Tsai et al., 2002; L'opez-Caballero et al., 2005; Sathivel et al., 2007). However, chitosan does not have significant antioxidant activity (Kanatt et al., 2008).

Spices and herbs have been used in many cuisines to impart flavour, aroma and pungency to food (Kanatt et al., 2008). Several studies have shown that the antimicrobial and antioxidative effect of chitosan was greatly enhanced by the addition of essential oils (Georgantelis et al. 2007; Kanatt et al., 2008).

Rosemary (Rosmarinus officinalis L.) extracts have also exhibited potent antioxidant activity and are widely used in the food industry. The antioxidant activity of rosemary extracts has been associated with the presence of several phenolic diterpenes such as carnosic acid, carnosol, rosmanol, rosmariquinone and rosmaridiphenol, which break free radical chain reactions by hydrogen atom donation (Aruoma et al. 1992; Basaga et al. 1997). A number of researchers have reported the effectiveness of rosemary extracts for achieving higher sensory scores and retarding lipid oxidation in various foods: Stoick et al. (1991). Incorporation of essential oils into chitosan films or coatings may not only enhance the film's antimicrobial and antioxidant properties but also reduce water vapour permeability and slow lipid oxidation of the product (Yanishlieva et al. 1999). Therefore development of natural preservative coatings or films with high antioxidant, antibacterial activities that prolong the shelf life of fish and fish products is needed.

The present study aims to evaluating the effect of chitosan with or without the addition of rosemary as a potent antioxidant in an attempt to extend the shelf life of tilapia fillets at refrigerated storage. Microbiological, chemical and sensory assessment were performed periodically at 0,3,6,9,12 and 15 days of storage at $4 \pm 1{ }^{\circ} \mathrm{C}$

\section{MATERIALS AND METHODS}

\subsection{Materials preparation}

$20 \mathrm{~kg}$ of freshwater nile tilapia ( average weight of 300-350 g / fish) were purchased from a local market of Alexandria. Fish were filleted by hand and transferred to the Laboratory in ice box tanks for further cleaning. Two fillets were obtained from each fish after removing the head and bone.

Chitosan of fine crystals purchased from a local company EL-HELW Co , Cairo .Rosemary(American gardens) was purchased from a super market in Jeddah (SA) by personal communication as whole ships.

Chitosan solution was prepared at $1.5 \%(\mathrm{w} / \mathrm{v})$ in $1 \% \mathrm{v} / \mathrm{v}$ acetic acid. To achieve complete dispersion of chitosan, solution was stirred at room temperature for $2 \mathrm{~h}$. The solution beakers were placed on a hotplate/magnetic 
stirrer, and glycerol was added to chitosan at $25 \%$ of chitosan weight concentration as a plasticizer and stirred for $10 \mathrm{~min}$. The resultant chitosan coating solution was filtrated through a Whatman No. 3 filter paper to remove any undissolved particles. Rosemary was washed with $1 \%$ acetic acid then was prepared as the chitosan solution. The mix of chitosan and rosemary solution was prepared with $1 \%(\mathrm{w} / \mathrm{v})$ chitosan and $1 \%(\mathrm{w} / \mathrm{v})$ rosmary in $1 \% \mathrm{v} / \mathrm{v}$ acetic acid following the same procedure of chitosan preparation. Fillet samples were randomly assigned into four lots consisting of ,one control lot (uncoated) and three lots treated with: chitosan $(C)$, rosemary $(R)$ and the $\operatorname{mix}(C+R)$. For each coated lot, approximately 20 fillets $(5 \times 12 \mathrm{~cm})$ were immersed for 30 minutes in $1500 \mathrm{ml}$ of the coating solution and then the fish fillets were removed and allowed to drain for $30 \mathrm{~min}$ on a metal sieve and then stored at $4 \pm 1{ }^{\circ} \mathrm{C}$ for subsequent quality assessment. Chemical, microbiological and sensorial analyses were performed at 3-day intervals to determine the overall quality of fish.

\subsection{Proximate chemical composition}

The moisture content and ash were determined in an oven at $103{ }^{\circ} \mathrm{C}$ and a muffle at $550{ }^{\circ} \mathrm{C}$, respectively, until a constant weight. The crude protein was determined by Kjeldahl's method (AOAC, 1984) and the lipid content was analyzed according to the procedure of Bligh and Dyer (1959).

\subsection{Bacteriological analysis}

Bacterial counts were determined by placing $10 \mathrm{~g}$ sample in $90 \mathrm{ml}$ of $0.85 \% \mathrm{NaCl}$ solution, and homogenized using a stomacher. From this dilution, other decimal dilutions were prepared and plated in the appropriate media. Total viable aerobic bacterial counts were determined by the pour plate method, using plate count agar (PCA,oxoid). The plates were incubated at $37{ }^{\circ} \mathrm{C}$ for 2 days for total viable counts. All counts were expressed as $\log 10 \mathrm{cfu} / \mathrm{g}$ and performed in duplicate (Arashisara et al., 2004).

\subsection{Determination of total volatile base nitrogen (TVB-N)}

Total volatile basic nitrogen (TVB-N) value was estimated by the microdiffusion method (Goulas and Kontominas, 2005). The microdiffusion method was applied by distillation after the addition of $\mathrm{MgO}$ to homogenized fish samples. The distillate was collected in a flask containing a $3 \%$ aqueous solution of boric acid and a mixed indicator produced from dissolution of $0.1 \mathrm{~g}$ of methyl red and $0.1 \mathrm{~g}$ of methylene blue to $100 \mathrm{ml}$ of ethanol.The boric acid solution was titrated with a $0.1 \mathrm{M}$ hydrochloric acid $(\mathrm{HCl})$ solution. The TVB-N value (mg N per100 $\mathrm{g}$ of fish) was estimated according to the consumption of hydrochloric acid. 


\subsection{Determination of thiobarbituric acid reactive substances (TBARSRS)}

The thiobarbituric acid value was determined colorimetrically by the method described by Kirk and Sawyer (1991). A portion (200 mg) of sample was weighed into a $25 \mathrm{ml}$ volumetric flask. An aliquot $(1 \mathrm{ml})$ of 1-butanol was added to dissolve the sample. The mixture was made to volume and mixed. A portion $(5.0 \mathrm{ml})$ of the mixture was pipetted into a dry stoppered test tube $5 \mathrm{ml}$ of TBARS reagent (prepared by dissolving $200 \mathrm{mg}$ of 2-TBARS in $100 \mathrm{ml} 1$ butanol, filtered, stored at $4^{\circ} \mathrm{C}$ for not more than 7 days) were added. The test tubes were stoppered, vortexed and placed in a water bath at $95^{\circ} \mathrm{C}$ for 120 min, then cooled. Absorbance $\left(A_{s}\right)$ was measured at $530 \mathrm{~nm}$ against water blank. A reagent blank was run and absorbance $\left(A_{b}\right)$ recorded. TBARS value ( $\mathrm{mg}$ of malonaldehyde equivalents $/ \mathrm{kg}$ of tissue) was obtained by the formula.

$$
T B A=\frac{50 x(\mathrm{Ab}-\mathrm{As})}{200}
$$

\subsection{Sensory evaluation}

The samples of raw fish fillet were evaluated by 6 trained panelists. The sensory evaluation was based on a five point scale to determine: overall acceptability (5, extremely desirable; 1 , extremely unacceptable) of the samples. Shelf-life criteria assumed that rejection would occur when the sensory attributes declined below 2.0.

\subsection{Statistical analysis}

All measurements were duplicated two times and mean values \pm standard error were reported for each case. Analysis of variance (ANOVA), Duncan's test, was performed on Statistical Analysis System (SAS) to evaluate the significance of differences among mean values.

\section{RESULTS AND DISCUSSION}

\subsection{Proximate composition}

The mean $( \pm S D)$ compositional contents of moisture, protein, lipid, and ash ( $\mathrm{g} / 100 \mathrm{~g}$ fish muscle) in the Nile tilapia (orechromis niloticus) fillets analyzed were $74.65 \pm 1.41,16.77 \pm 0.36,1.8 \pm 0.24$, and $3.11 \pm 0.29$, respectively (Table 1 ). Such variations in the chemical composition of fish is strongly related to the nutrition, catching season (spawning cycles), sexual variation, fish size, living area, as well as the other environmental conditions (Gonza'lez-Fandos et al. , 2005). The compositional variation, due to the reasons mentioned above, may possibly lead to changes in the sensory attributes, such as taste, odour, texture, colour, and surface appearance, which control the acceptability of fish as food (Gonza'lez-Fandos et al. , 2004; Ibrahim, 2007), and may affect the microbial growth (Gonza'lez-Fandos et al. , 2005). 
Table 1. Proximate chemical composition of tilapia fillets (on wet bases)

\begin{tabular}{ll}
\hline Proximate chemical constituents & $\mathbf{g} / \mathbf{1 0 0} \mathbf{g}$ fish muscle \\
\hline Moisture & $74.65 \pm 1.41$ \\
Crude protein & $16.77 \pm 0.36$ \\
Lipid & $1.8 \pm 0.24$ \\
Ash & $3.11 \pm 0.29$ \\
\hline
\end{tabular}

Means of triplicate $( \pm S D)$.

The fish were purchased in may 2014 .

\subsection{Bacteriological analysis}

Variations in the value of total viable counts (TVC) during the refrigerated storage are presented in Fig. 1. The initial TVC $\left(\log _{10} \mathrm{CFU} / \mathrm{g}\right)$ in Nile tilapia fillets ranged from 3.73 in C + R-coated samples to 4.10 in control. The increase of TVC in fish flesh during storage has been demonstrated by Fan et al. (2008). By the day 9 of storage, however, TVC of Nile tilapia fillets for all of the treatments was still below $6 \log _{10} \mathrm{CFU} / \mathrm{g}$, while that of controls attained a count of 7.25 at the $9^{\text {th }}$ day, which is higher than the maximal recommended limit of 7 $\log _{10}$ CFU/g for TVC in raw fish (Ibrahim, 2007), indicating a microbiological shelf life of less than 9 days for the control samples. On the other hand, $\mathrm{C}+\mathrm{R}$ treatment was still under $6 \log _{10} \mathrm{CFU} / \mathrm{g}$ up to 12 days. The antimicrobial properties of chitosan coating have been reported in the literature (L'opezCaballero et al., 2005 Jeon et al., 2002; Tsai et al., 2002). Jeon et al. (2002) described the bacterial growth (total counts on plate count agar at $20{ }^{\circ} \mathrm{C}$ ) reached the stationary phase in all chitosan-coated cod and herring samples after 6 days, and also there was a reduction of up to three log cycles between coated samples and controls after 12 days of chilled storage. Also Tsai et al. (2002) found that pretreatment of fish fillets (Oncorhynchus nerka) for $3 \mathrm{~h}$ with $1 \%$ chitosan solution retarded the increase in the counts for mesophiles, psychrotrophs, coliforms, Aeromonas species, and vibrio species. L'opezCaballero et al. (2005) reported that a coating consisting of a blend of chitosan dissolved in acetic acid and gelatin exerted an inhibitory effect on the gramnegative flora of fish patties. Various factors affect the antimicrobial action of chitosan and its mechanism of action appears to be related to interactions between the positively charged chitosan molecules and the negatively charged microbial cell membrane (Shahidi et al., 1999) as well as to its function as a barrier against oxygen transfer (Jeon et al., 2002). 


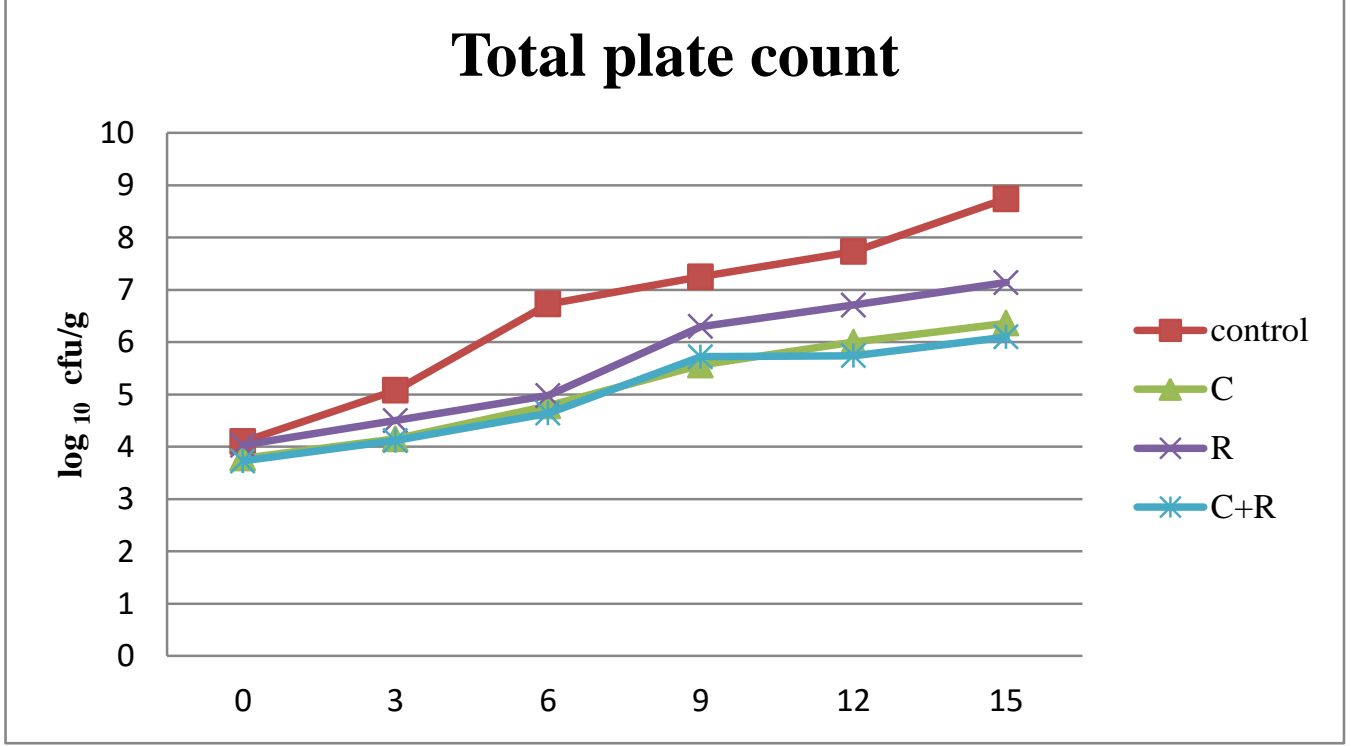

storage time ( days )

Fig. 1. Changes in total viable counts (TVC) of fish samples during refrigerated storage.

\subsection{Total volatile base nitrogen (TVB-N)}

The TVB-N values for the treatments during storage are presented in

Fig. 2. The initial TVB- $N$ values (mg $N$ per $100 \mathrm{~g}$ fish) ranged from 13.80 in $R$ coated samples to 13.86 in $\mathrm{C}+\mathrm{R}$ coated .

TVB-N values of both controls and the coated samples increased significantly ( $p$ $<0.01$ ) with storage time. By the end of the storage period (day 15), however, the samples coated with $C+R$ reached a significantly $(p<0.01)$ lower TVB-N value of 32.41 in comparison with the samples coated with $\mathrm{C}, \mathrm{R}$ or controls, which attained higher levels of 35.50, 44.38 and 56.68, respectively (Fig. 2).

Since TVB-N is produced mainly by bacterial decomposition of fish flesh, the higher values of total viable counts of uncoated vs. coated samples after 12 days in refrigerated storage could account for the higher TVB-N values of uncoated samples.

Using cod and herring fillets and different types of soluble chitosan coatings, (Jeon et al. ,2002) reported reduction of $33-50 \%$ and $26-51 \%$, respectively, in TVB-N formation at the end of a 12-day storage period. Also Tsai et al. (2002) found that pretreatment of fish fillets (O. nerka) with $1 \%$ chitosan solution for $3 \mathrm{~h}$ retarded the increase in the TVB-N. L 'opez-Caballero et al. (2005) found that the chitosan-gelatin coating lowered TVB-N values distinctly and hence slowed spoilage.

In the present study, also the TVB-N content was significantly lower $(p<0.01)$ in samples coated with $\mathrm{C}+\mathrm{R}$ than in samples coated with $\mathrm{C}$ or $\mathrm{R}$. This can be attributed to either a more rapidly reduced bacterial population or decreased 
capacity of bacteria for oxidative de-amination of non-protein nitrogen compounds or both (Fan et al., 2008) . Nevertheless, the combination of $\mathrm{C}+\mathrm{R}$ seem to exert a synergistic effect rather than each of them alone .

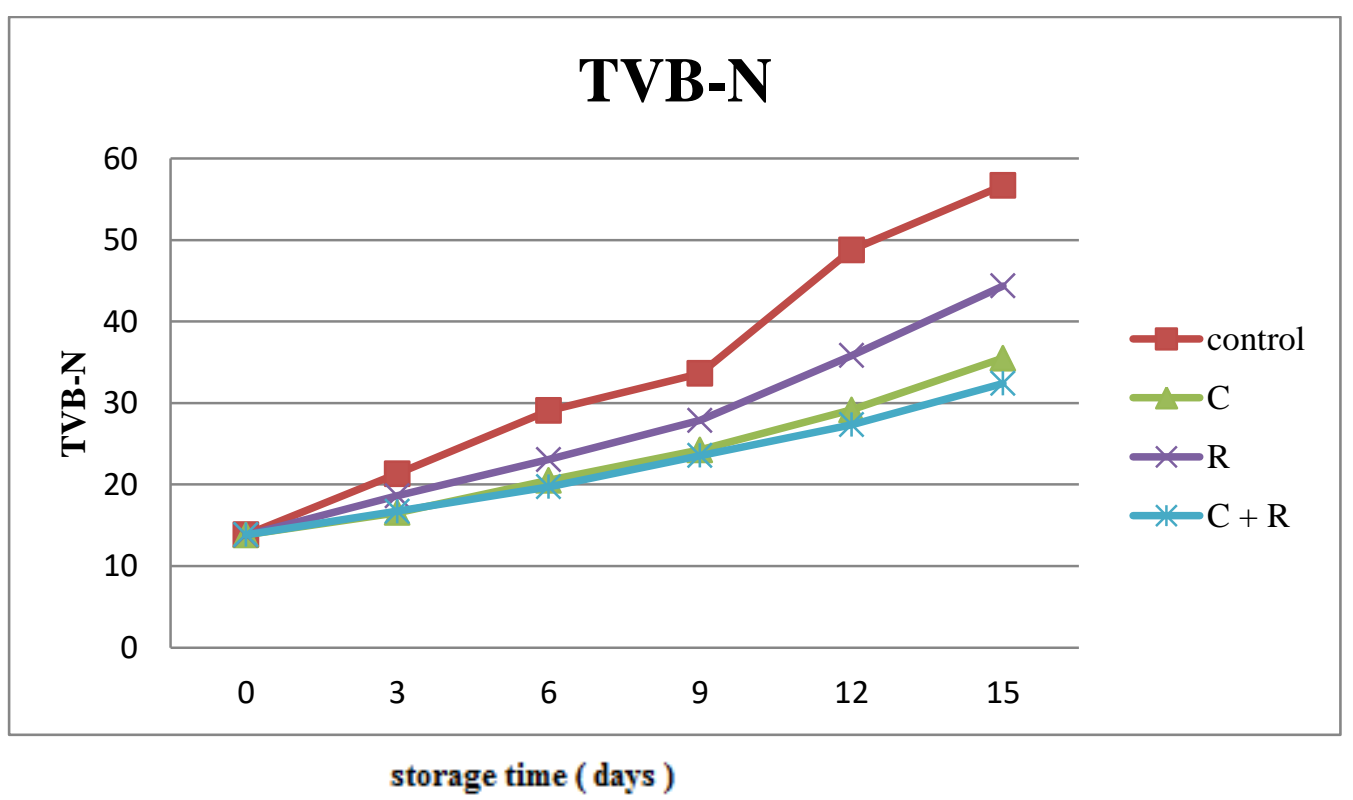

Fig. 2. Changes in TVB-N values of fish samples during refrigerated storage.

\subsection{Thiobarbituric acid reactive substances (TBARS)}

Thiobarbituric acid reactive substances (TBARS) are widely used as indicator for the assessment of degree of lipid oxidation (Ibrahim, 2007 and Jeon et al., 2002). In Fig. 3 the TBARS values for the different treatments during storage are presented. The initial TBARS values ( $\mathrm{mg}$ of malonaldehyde equivalents $/ \mathrm{kg}$ of tissue) ranged from 0.10 in $\mathrm{C}+\mathrm{R}$ - coated sample to 0.11 in $\mathrm{C}$, $R$ and controls. TBARS values of the control and coated samples increased with storage time. By the end of the storage period (day 15), however, $\mathrm{C}+\mathrm{R}$ and R-coated samples reached significantly $(p<0.01)$ lower TBARS values of 0.25 and $0.26 \mathrm{mg}$ of malonaldehyde equivalents $/ \mathrm{kg}$ of tissue in comparison with the control or C-coated samples, which attained a higher level of 0.56 and $0.35 \mathrm{mg}$ of malonaldehyde equivalents/kg of tissue, respectively (Fig. 3).

It has been proposed that the maximum level of TBARS value indicating good quality of the fish (frozen, chilled or stored with ice) is $5 \mathrm{mg}$ of malonaldehyde equivalents $/ \mathrm{kg}$ of tissue, while the fish may be consumed up to the level of $8 \mathrm{mg}$ of malonaldehyde equivalents $/ \mathrm{kg}$ of tissue (Ibrahim, 2007). In the current study,TBARS values for control and coated Nile tilapia fillet samples analyzed were much lower than such proposed limits throughout the 15-days storage period.

Jeon et al. (2002) found lower contents of TBARSRS in chitosan-coated herring and cod samples than those of the uncoated samples throughout the storage time. Both antioxidant and oxygen barrier properties of chitosan may 
have contributed to the control of lipid oxidation in the rainbow trout fillets. The antioxidant properties of chitosan in foods have been reported (Shahidi et al., 1999). The antioxidation mechanism of chitosan could be explained as the primary amino groups of chitosan would form a stable fluorosphere with volatile aldehydes such as malondialdehyde, which is derived from breakdown of fats during the oxidation (Shahidi et al., 1999). In addition, chitosan coating and film have been known to be good barriers to oxygen permeation (Sathivel et al., 2007). Sathivel et al. (2007) found that chitosan glazing applied on the surface of pink salmon fillets acted as a barrier between the fillet and the surrounding air, slowing down the diffusion of oxygen from the surroundings via the surface into the fillet. Georgantelis et al. (2007) reported that the antioxidative effect of chitosan was greatly enhanced by the addition of rosemary extract to chitosan . Tromb-etta, et al. (1998) correlated the antioxidant effect of cinnamon with that of the phenolic concentration (hydroxycinnamaldehyde, hydroxycinnamic acid, etc.) of the extract.

In this study, the $\mathrm{C}+\mathrm{R}$-coated samples showed a lower TBARS in comparison with C-coated samples on Nile tilapia fillets (Fig. 3). Adding rosemary extract to chitosan coating, therefore, probably had a synergistic effect. In the case of most herbal extracts, their antioxidant activity has been attributed to their ability to break the free radical chain by donating a hydrogen atom (Pin-Der-Duh, 1998).

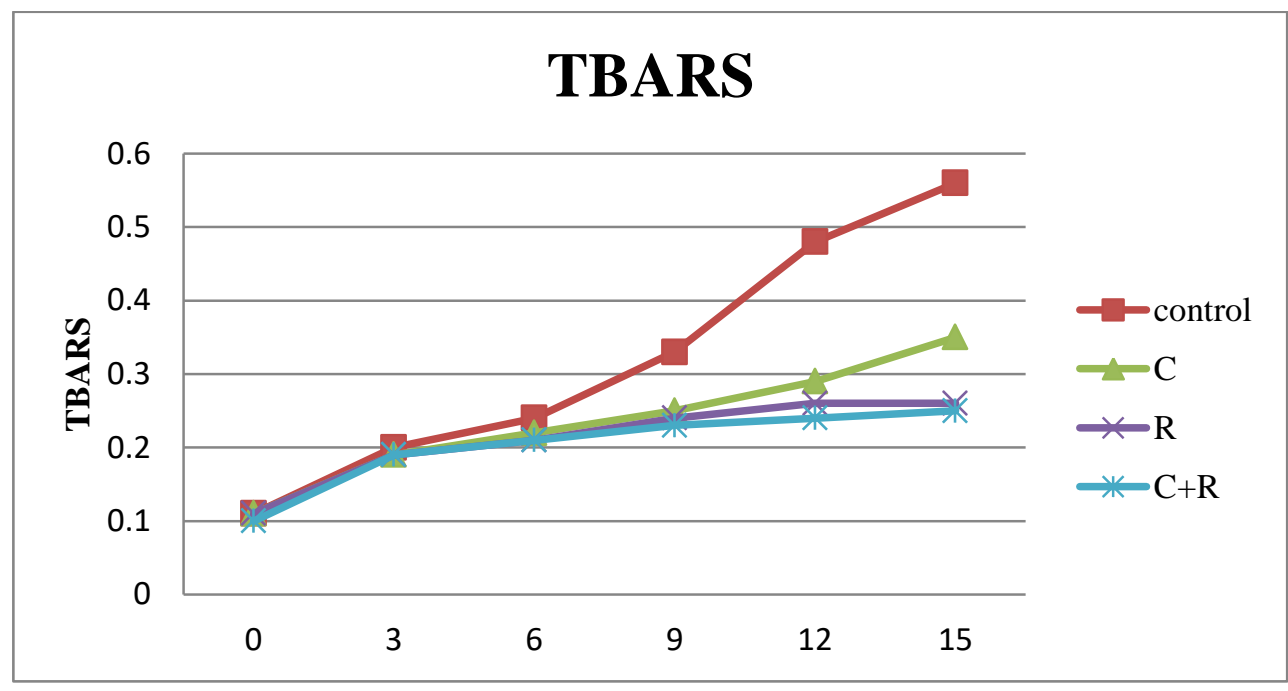

storage time ( days )

Fig. 3. Changes in TBARS values of fish samples during refrigerated storage.

\subsection{Sensory evaluation}

The results of the sensory assessment of samples are given in Table 2. The fish samples were considered to be acceptable for human consumption until the sensory score reached 2 (Fan et al.,2008). Overall acceptability of control samples were given 'unacceptable' scores by the $6^{\text {th }}$ day. The sensory 
evaluation results appeared to be correlated to microbial and chemical value analyses. Due to high lipid oxidation and microbial growth, the control samples (uncoated) of Nile tilapia fillets showed spoilage, appearing as off-odour, slimy with discoloration after 6 days refrigerated storage. The antioxidant, antimicrobial and gas barrier effects by coating have been shown to minimize the oxidative effects, prolonging the product shelf life while maintaining quality. Adding rosemary to chitosan coating enhanced significantly $(p<0.01)$ the beneficial effects on overall acceptability of the fish in final days.

Table .2. Overall acceptability of refrigerated tilapia fillets treated with different coatings during storage.

\begin{tabular}{|c|c|c|c|c|c|c|c|}
\hline \multirow{2}{*}{ Treatment } & \multicolumn{6}{|c|}{ Storage time ( days ) } & \multirow{2}{*}{$\begin{array}{c}\text { Overall } \\
\text { mean }\end{array}$} \\
\hline & 0 & 3 & 6 & 9 & 12 & 15 & \\
\hline control & $\begin{array}{r}4.80^{a} \\
\pm 0.20\end{array}$ & $\begin{array}{l}3.60^{b} \\
\pm 0.24\end{array}$ & $\begin{array}{l}2.60^{c d} \\
\pm 0.00\end{array}$ & $\begin{array}{c}1.60^{\text {defg }} \\
\pm 0.24\end{array}$ & $\begin{array}{l}1.20^{\mathrm{fg}} \\
\pm 0.20\end{array}$ & $\begin{array}{r}1.00^{g} \\
\pm 0.00\end{array}$ & $\begin{array}{l}2.37^{C} \\
\pm 0.26\end{array}$ \\
\hline C & $\begin{array}{l}4.80^{a} \\
\pm 0.20\end{array}$ & $\begin{array}{l}4.60^{a} \\
\pm 0.24\end{array}$ & $\begin{array}{l}3.80^{b} \\
\pm 0.20\end{array}$ & $\begin{array}{l}3.20^{b} \\
\pm 0.20\end{array}$ & $\begin{array}{l}2.55^{d} \\
\pm 0.20\end{array}$ & $\begin{array}{l}1.40^{\text {efg }} \\
\pm 0.24\end{array}$ & $\begin{array}{l}3.33^{A} \\
\pm 0.24\end{array}$ \\
\hline $\mathbf{R}$ & $\begin{array}{r}4.80^{a} \\
\pm 0.20\end{array}$ & $\begin{array}{l}4.80^{a} \\
\pm 0.20\end{array}$ & $\begin{array}{l}3.40^{b} \\
\pm 0.24\end{array}$ & $\begin{array}{l}2.52^{d} \\
\pm 0.32\end{array}$ & $\begin{array}{l}1.40^{\text {efg }} \\
\pm 0.24\end{array}$ & $\begin{array}{r}1.00^{g} \\
\pm 0.00\end{array}$ & $\begin{array}{l}2.90^{\mathrm{B}} \\
\pm 0.30\end{array}$ \\
\hline$C+R$ & $\begin{array}{r}4.80^{a} \\
\pm 0.20\end{array}$ & $\begin{array}{l}4.60^{a} \\
\pm 0.24\end{array}$ & $\begin{array}{l}3.80^{b} \\
\pm 0.20\end{array}$ & $\begin{array}{l}3.20^{b} \\
\pm 0.20\end{array}$ & $\begin{array}{l}2.65^{c} \\
\pm 0.24\end{array}$ & $\begin{array}{l}1.80 \text { def } \\
\pm 0.20\end{array}$ & $\begin{array}{l}3.43^{A} \\
\pm 0.22\end{array}$ \\
\hline $\begin{array}{c}\text { Overall } \\
\text { mean }\end{array}$ & $\begin{array}{l}4.80^{\mathrm{A}} \\
\pm 0.09\end{array}$ & $\begin{array}{l}4.40^{\mathrm{B}} \\
\pm 0.15\end{array}$ & $\begin{array}{l}3.25^{C} \\
\pm 0.19\end{array}$ & $\begin{array}{l}2.50^{\mathrm{D}} \\
\pm 0.20\end{array}$ & $\begin{array}{l}1.80^{\mathrm{E}} \\
\pm 0.16\end{array}$ & $\begin{array}{l}1.30^{\mathrm{F}} \\
\pm 0.11\end{array}$ & \\
\hline
\end{tabular}

$\overline{A-F}$ Means within each column followed by the same letter are not significantly different $(P>0.01$ ) from each other .

A-C Means within each row followed by the same letter are not significantly different $(P>0.01$ ) from each other .

a-g Means of interaction between treatment and time followed by the same letter are not significantly different $(P>0.01$ ) from each other .

C : coated with chitosan solution.

$R \quad$ : coated with rosemary solution.

$\mathrm{C}+\mathrm{R}$ : coated with mix of chitosan and rosemary solution.

\section{CONCLUSIONS}

Successful inhibition of lipid oxidation and microbial growth in refrigerated Nile tilapia (orechromis niloticus) fillets was possible with $C+R$ (chitosan and rosmary) coating, as together they kept the sensory characteristics within acceptable limits throughout storage. $C+R$ treatment 
could maintain tilapia fillet shelf life up to 9-12 days without any significant loss of overall acceptability and without significant microbial growth, while control samples had a shelf life of only 6 days. Therefore, chitosan coating together with rosemary provides a type of active coating that can be utilised as a safe preservative for fish under refrigerated storage.

\section{REFERENCES}

AOAC (1984). Official methods of analysis (14 ${ }^{\text {th }}$ ed.). Washington, DC: Association of Official Analytical Chemists.

Arashisara, S ., Hisara, O., Kayab, M., and Yanik, T. (2004). Effects of modified atmosphere and vacuum packaging on microbiological and chemical properties of rainbow trout (Oncorynchus mykiss) fillets. International of Food Microbiology, 97: 209-214.

Aruoma, O. I., Halliwell, B., Aeschbach, R., and Lo ' liger, J. (1992). Antioxidant and pro-oxidant properties of active rosemary constituents: carnosol and carnosic acid. Xenobiotica, 22(2): 257-268.

Basaga, H., Tekkaya, C., and Acitel, F. (1997). Antioxidative and free radical scavenging properties of rosemary extract. Lebensmittel -Wissenschaft und Technologie, 30 (1): 105-108.

Bligh, E. G., and Dyer, W. J. (1959). A rapid method of total lipid extraction and purification. Canadian Journal of Biochemistry Physiology, 37: 911917.

Bonilla, J., Atarés, L., Vargas, M., and Chiralt, A. (2012). Effect of essential oils and homogenization conditions on properties of chitosan-based films. Food Hydrocolloids, 26: 9-16

Cagri, A., Ustunol, Z., Ryser, E.T.( 2004). Antimicrobial edible films and coatings. J. Food Prot. 67, 833-848. Centers for Disease Control and Prevention, 1999. Update: multistate outbreak of listeriosis-United States, 1998-1999. Morb. Mortal. Wkly. Rep., 47: 1117-1118.

Campos, C. A., Gerschenson, L. N., and Flores, S. K. (2011). Development of edible films and coatings with antimicrobial activity. Food Bioprocess Technol., 4: 849-875. doi: 10.1007/s11947-010-0434-1

Chen, C.S., Liau, W.Y.and Tsai, G.J.( 1998). Antibacterial effects of Nsulfobenzoyl chitosan and application to oyster preservation. J. Food Prot., 61: 1124-1128.

Darmadji, P.and Izumimoto, M.(1994). Effect of chitosan in meat preservation. Meat Sci., 38: 243-254.

Fang, S.W., Li, C.J.and Shin, D.Y.C.(1994). Antifungal activity of chitosan and its preservative effect on low-sugar candied kumquat. J. Food Prot., 56: 136-140.

Fan, W., Chi, Y., and Zhang, S. (2008). The use of a tea polyphenol dip to extend the shelf life of silver carp (Hypophthalmicthys molitrix) during storage in ice. Food Chemistry, 108: 148-153. 
Georgantelis, D., Ambrosiadis, I., Katikou, P., Blekas, G., and Georgakis, S. A. (2007). Effect of rosemary extract, chitosan and a-tocopherol on microbiological parameters and lipid oxidation of fresh pork sausages stored at $4^{\circ} \mathrm{C}$. Meat Science, 76: 172-181.

Gonza'lez-Fandos, E., Garcı'a-Linares, M. C., Villarino-Rodrı'guez, A., Garcı'a-Arias, M. T., and Garcı'a-Ferna'ndez, M. C. (2004). Evaluation of the microbiological safety and sensory quality of rainbow trout (Oncorhynchus mykiss) processed by the sous vide method. Food Microbiology, 2: 193-201.

Gonza'lez-Fandos, E., Villarino-Rodrı'guez, A., Garcı'a-Linares, M. C., Garcı'a-Arias, M. T., and Garcı'a-Ferna'ndez, M. C. (2005). Microbiological safety and sensory characteristics of salmon slices processed by the sous vide method. Food Control, 16: 77-85.

Goulas, A. E., and Kontominas, M. G. (2005). Effect of salting and smokingmethod on the keeping quality of chub mackerel (Scomber japonicus): Biochemical and sensory attributes. Food Chemistry, 93: 511-520.

Ibrahim, S. K. (2007). Antimicrobial and antioxidant effects of sodium acetate, sodium lactate, and sodium citrate in refrigerated sliced salmon. Food Control, 18: 566-575.

Jeon, Y.I., Kamil, J. Y. V. A., and Shahidi, F. (2002). Chitosan as an edible invisible film for quality preservation of herring and Atlantic cod. Journal of Agricultural and Food Chemistry, 20: 5167-5178.

Kanatt, S. R., Chander, R., and Sharma, A. (2008). Chitosan and mint mixture: A new preservative for meat and meat products. Food Chemistry, 107: 845-852.

Kendra, D.F.and Hadwiger, L.A.( 1984). Characterization of the smallest chitosan oligomer that is maximally antifungal to Fusarium solani and elicits pisatin formation in Pisum sativum. Exp. Mycol. , 8: 276-281.

Kirk, R. S., and Sawyer, R. (1991). Pearson's composition and analysis of foods pp. 640, 643 ( $9^{\text {th }}$ ed). UK: Longman Scientific and Technical.

Knorr, D.( 1984). Use of chitinous polymers in food-a challenge for food research and development. Food Technol. , 38: 85-97.

Kong, M., Chen, X.G., Xing, K., Park, H.J.( 2010). Antimicrobial properties of chitosan and mode of action: A state of the art review. Int. J. Food Microbiol., 144: 51-63.

L'opez-Caballero, M. E., G'omez-Guill'en, M. C., P'erez-Mateos, M., and Montero, P. (2005). A chitosan-gelatin blend as a coating for fish patties. Food Hydrocolloids, 19: 303-311.

Muzzarelli, R.A.A.( 1977). Chitin. Pergamon, Oxford, UK.

No, H.K., Park, N.Y., Lee, S.H., Samuel, P.M.( 2002). Antibacterial activity of chitosans and chitosan oligomers with different molecular weights. Int. J. Food Microbiol. , 74: 65-72. 
Pin-Der-Duh, X. (1998). Antioxidant activity of Budrock (Arctium lappa L.): It's scavenging effect on free radical and active oxygen. of American Oil Chemist Society, 75: 455-461.

Sathivel, S., Liu, Q., Huang, J., and Prinyawiwatkul,W. (2007). The influence of chitosan glazing on the quality of skinless pink salmon (Oncorhynchus gorbuscha) fillets during frozen storage. Journal of Food Engineering, 83: 366-373.

Sekiguchi, S., Miura, Y., Kaneko, H., Nishimura, S.I., Nishi, N., Iwase, M., Tokura, S.( 1994). Molecular weight dependency of antimicrobial activity by chitosan oligomers. In: Nishinari, K., Doi, E. (Eds.), Food Hydrocolloids: Structures, Properties, and Functions. Plenum Press, New York, NY, pp. 71-76.

Shahidi, F., Arachchi, J. K. V., and Jeon, Y. J. (1999). Food applications of chitin and chitosans. Trends in Food Science and Technology, 10 (2): 37-51.

Stoick, S. M., Gray, J. L., Booren, A. M., and Buckley, D. J. (1991). Oxidative stability of restructured beef steaks processed with oleoresin rosemary, tertiary butylhydroquinone and sodium tripolyphosphate. of Food Science, 56 (3): 597-600.

Sudarshan, N.R., Hoover, D.G.and Knorr, D.( 1992). Antibacterial action of chitosan. Food Biotechnol. , 6: 257-272.

Sugano, M., Fujikawa, T., Hiratsuji, Y., Nakashima, N., Fukuda, N., Hasegawa, Y.(1980). A novel use of chitosan as a hypocholesterolemic agent in rats. Am. J. Clin. Nutr. , 33: 787.

Suzuki, K., Mikami, T., Okawa, Y., Tokoro, A., Suzuki, S., Suzuki, M.( 1986). Antitumor effect of hexa-N-acetylchitohexaose and chitohexaose. Carbohydr. Res. , 151: 403.

Trombetta, D., Lo Casero, R., Pellegrino, M. L., and Tomarino, A. (1998). Antioxidant properties and phenolic content of essential oils from Mediterranean plants. Fitoterapia, 69: 42.

Tsai, G.and Su, W.( 1999). Antibacterial activity of shrimp chitosan against Escherichia coli. J. Food Prot. , 62: 239-243.

Tsai, G. J., Su, W. H., Chen, H. C., and Pan, C. L. (2002). Antimicrobial activity of shrimp chitin and chitosan from different treatments and applications of fish preservation. Fisheries Science, 68: 170-177.

Tsai, G., Zhang, S.and Shieh, P.( 2004). Antimicrobial activity of a lowmolecular weight chitosan obtained from cellulose digestion of chitosan. J. Food Prot., 67: 396-398.

Tokoro, A., Tatewari, N., Suzuki, K., Mikami, M., Suzuki, S.and Suzuki, M. (1988). Effect of hexa-N-acetylchitohexaose and chitohexaose against Meth-A solid form. Chem. Pharm. Bull., 36: 784.

Yanishlieva, N. V., Marinova, E. M., Gordon, M. H., and Raneva, V. G. (1999). Antioxidant activity and mechanism of action of thymol and carvacrol in two lipid systems. Food Chemistry, 64: 59-66. 


\section{الملخص العربى}

\section{تأثير استخدام الشيتوزان و الروزمارى فى إطالة عمر شرائح البلطى النيلى المبردة}

\section{احمد حسن احمد ، أميمة شلتوت ، أيمن ابواليزيل ، ناجى منصور خضرجى}

قسم علوم الأغذية ، كلية الزراعة (سابا باشا )، جامعة الاسكندرية

أجريت هذه الدراسة بغرض إختبار تأثير الثيتوزان وبعض الأعثاب الطبيعية " روزمارى " فى إطالة عمر

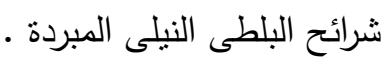

تم تحضير ثلاث معاملات مختلفة _ بالإضافة الى الكنترول _ هى الثينوزان ، الروزمارى و خليط منهما

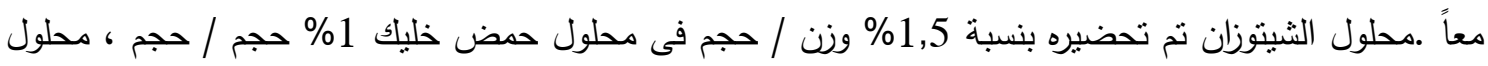

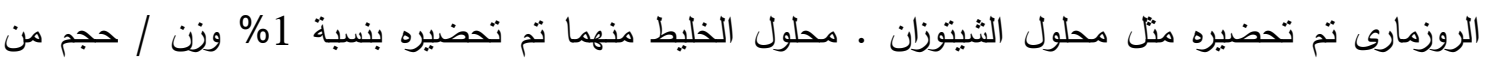
الثيتوزان مع 1\% وزن / حجم من الروزمارى فى محلول حمض خليك 1\% حجم / حجم وبنفس خطوات تحضير

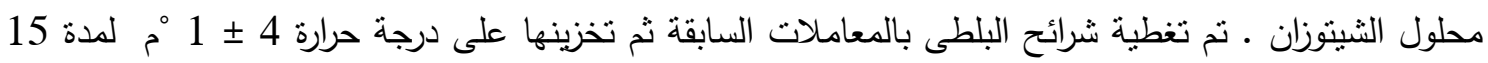

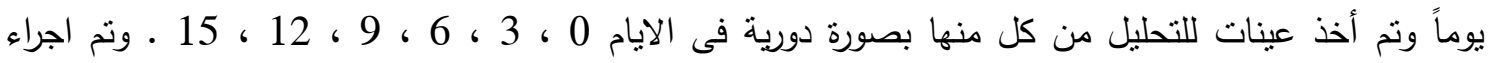

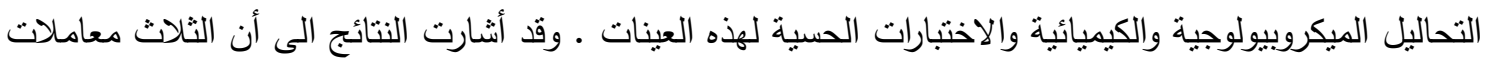
يمكنها بفاعلية الحفاظ على جودة شرائح البلطى واطالة عمرها الافتراضى بما يساوى 3 الى 6 ايام اكثر من مجموعة الكنترول خلال فترة تخزينهم تحت تبريد . 
